\title{
LA MODERNIDAD EN LLAMAS: NIETZSCHE Y HEIDEGGER
}

Modern Age is burning: Nietzsche and Heidegger

\author{
Alberto Constante \\ UNAM, México
}

«Cada pensador piensa sólo un único pensamiento».

(M. Heidegger)

«El pesimismo moderno es una expresión de la inutilidad del mundo moderno - no del mundo y de la existencia».

(F. Nietzsche)

RESUMEN: La controversia de Heidegger con Nietzsche tiene una meta próxima y una lejana: la meta próxima es exponer que en el pensamiento de Nietzsche habita una metafísica y que ésta es la que marca nuestra época; la meta lejana consiste para Heidegger en hacer patente que la metafísica se expresa en nuestra época mediante el dominio tecnológico de la tierra y que quizá sea posible otro inicio que no sea el de la metafísica. Pero lo importante es escuchar a Nietzsche, preguntar con él, por él, y eso quiere decir preguntar al mismo tiempo contra él, pero en favor de la filosofía occidental

Palabras clave: Nietzsche - Heidegger - metafísica-dominio de la tierra-el otro inicio

ABSTRACT: The controversy of Heidegger with Nietzsche has a close goal and a distant one: the close goal is the exhibition of the internal unity of the fundamental Metaphysical position of Nietzsche, according to the position of attention of our time; the distant goal is the unfolding of the question if the supreme struggle is then the Metaphysical fight for earth dominion or if what happens in history can find another beginning that is not already Metaphysical. Nevertheless, the decisive point continues to be hearing Nietzsche, to ask with him, by him and through him, and that means: to ask at the same time against him, but in favour of the unique cause, the common and more intimate cause of western philosophy.

Keywords: Nietzsche - Heidegger - Metaphysics - earth ominion - the other beginning

\section{LOS CLÁSICOS: NIETZSCHE, UN ENIGMA A DESCIFRAR}

"Clásicos son aquellos textos que sobreviven a sus interpretaciones». Ese es el escenario en donde bailan y danzan los crepúsculos y las esferas de Sloterdijk en su ensayo sobre Nietzsche ${ }^{1}$. Y no le faltó razón.

1. P. Sloterdijk, Der Denker auf der Bühne. Nietzsches Materialismus, Frankfurt a. M.: Suhrkamp, 1986 (El pensador en escena. El materialismo de Nietzsche, Valencia: Pre Textos). 
Cuanto más son objeto de disección, tanto más elusivos parecen. Cuanto más persistentemente se les intenta conquistar por la comprensión, tanto más fría es la mirada que lanzan a sus suprasensibles pretendientes. Cuanto más profunda es la iluminación hermenéutica de sentido o cuanto más penetra la reconstrucción filológica en el entramado del texto clásico, con más dureza resiste el impacto de las interpretaciones ${ }^{2}$.

La ventura y desventura de Nietzsche consiste en haber desfallecido en manos de un sinnúmero de intérpretes. Yo entre ellos, desde luego. Estoy persuadido de que esta gigantomaquia que se ha hecho del incendiado de Turín ha contribuido tanto a la fascinación que sentimos por él como a su incomprensión. ¿Cómo someter ese pensamiento a un espíritu de sistema si él mismo se niega a ser sistematizado? ¿Acaso el mismo profesor de Basilea no señalaba en el Crepúsculo de los ídolos su enorme desconfianza en los grandes espíritus sistemáticos? «Desconfío de todos los sistemáticos y los evito. El gusto por el sistema es una falta de probidad ${ }^{3}$. Entonces, ¿cómo someter a una ratio un pensar que se conduce como una ruptura, como una fragmentación, una lucha contra la imposición, es decir, del cálculo y la medida, o lo que en otros términos se denominó el proyecto de la matematización de la naturaleza?

$\mathrm{Y}$, sin embargo, hoy, aquí, estamos enfrascados en desentrañar los misterios de ese pensamiento críptico, ese pensamiento que parece condenarnos al adjetivo, donde parece que quedamos reducidos al dilema entre lo predicable y lo inefable, ese pensamiento donde "el desierto crece». Cuando se entra en el gran teatro Nietzscheano cobra en nosotros fisonomía y perfil un raro desasosiego que se filtra cuando tiemblan los fundamentos que dan credibilidad a todo cuanto nos ha sido lo más familiar, el cimiento de nuestras certezas, la base de nuestras seguridades, de nuestras percepciones e ideaciones y, lo que es más grave, de nuestras prácticas que son las que consienten en eso que llamamos «realidad» y que es sólo el resultado de la persistencia y aglomeración de recuerdos indivisos y vividos por nosotros con una ilusoria inmediatez del presente. En medio de esta zozobra, nos asalta la curiosidad por asistir a esta fiesta orgiástica de lo que podríamos llamar nuestra modernidad en llamas, en la cual la vida pierde su odiosa gravedad y todo se mezcla con todo. Sin duda, Nietzsche puede ser llamado el artífice de este fuego.

Siempre he tenido innumerables reparos a tratar de manera sistemática el pensamiento del «loco de Turín», quizá porque desespero del mismo dictamen de este pensador, en el sentido de que la fuerza de una interpretación que quiere llegar al fondo de las cosas descubre que ese fondo no es más que otra interpretación. Más aún, diría que el anhelo de verdad que motiva al intérprete en su lectura lo conduce a descubrir que esa misma verdad sólo es una máscara: Nietzsche nos advierte: «Todo lo que es profundo ama la máscara; las cosas más profundas de todas sienten incluso odio por la imagen y el símbolo» ${ }^{4}$. Es decir, si todo es una interpretación, entonces, todo tiene que ser una máscara más detrás de otra y de otra, la máscara de la máscara, sin llegar a la última como supondría el pensar de causas y principios. No hay nada definitivo ni cierto, sólo una

2. Ibid., p. 13.

3. Citado en F. Nietzsche, Inventario, ed. de F. Savater, Madrid: Taurus, 1973, p. 104.

4. M, KSA III 24. 
máscara que oculta una distinta y con ella devela otra máscara. La máscara está vacía; lo que importa es el acto mismo de la máscara, la función que tiene en el sentido trágico de la vida. La identidad está en juego. Es decir, que todo tiene un origen discursivo y no trascendental. De ahí que «la muerte de Dios» remate en la evidencia de que el uso de la verdad no puede sustraerse a una cierta dosis de discrecionalidad y, en cuanto tal, es susceptible de manipulación. ¿De qué se trata, pues? ¿De un ritual de adiós? ¿De una renovación? Recordaría que no hay original de la máscara, que el modelo mismo es el calco; no hay un hecho, sólo interpretaciones, no hay sentido propio de la palabra, sólo sentidos figurados, los conceptos son sólo metáforas disfrazadas; no hay versión auténtica del texto, sólo traducciones; no hay verdad, sólo formas de apropiarse de lo lejano. La máscara fue sin duda el modo de apropiación de un mundo lejano. Baste recordar aquí aquellas palabras de Nietzsche del que Heidegger dijera que su rigor sólo era comparable al de Aristóteles, Schelling, Hegel o al de Leibniz:

Y por lo que se refiere a nuestro porvenir costará trabajo encontrarnos en la pista de esos jóvenes egipcios que rondan por la noche violando los templos, abrazan las estatuas y quieren desnudar completamente, descubrir, sacar a plena luz, lo que por buenas razones estaba oculto. Nosotros ya no encontramos placer en esa cosa de mal gusto, la voluntad de verdad, de la «verdad a toda costa», esa locura de joven enamorado de la verdad; tenemos demasiada experiencia para ello, somos demasiado serios, demasiado alegres, estamos demasiado probados por el fuego, somos demasiado profundos... Ya no creemos que la verdad siga siendo verdad cuando se le quita su velo, hemos vivido demasiado para creerlo. Para nosotros hoy es cuestión de conveniencia no querer verlo todo desnudo, no querer asistir a todas las cosas, no querer comprenderlo y saberlo todo ${ }^{5}$.

Descreo entonces de que el pensamiento del maestro de Basilea esté desnudo de secretos. Más bien estoy convencido de que su pensamiento se halla aún, en cierta medida, intacto y en posesión de muchos de sus enigmas. Ésta, como puede advertirse ya, desde un principio, es sólo una interpretación más y por ello está cargada de subjetividad. Nosotros somos «sólo los intérpretes de interpretaciones», decía Montaigne que se hacía eco de la descripción que daba Platón del rapsoda como hermêneôn hermêneus en el Ión, es decir, de aquel que era intérprete de la voluntad de los dioses e intérprete de otros rapsodas. No le faltaba razón a Montaigne. Tampoco a Nietzsche cuando pudo escribir en el borde de la oscuridad en Ecce homo:

Sé cuál es mi suerte. Un día mi nombre irá unido a algo gigantesco, al recuerdo de una crisis como jamás la ha habido en la Tierra, del más profundo enfrentamiento de conciencia, de un juicio definitivo mediante un conjunto contra todo lo que hasta ese momento se había creído, exigido y santificado. Yo no soy un hombre, soy dinamita ${ }^{6}$.

¿Cuál fue ese «algo gigantesco» al que se refiere Nietzsche? ¿Cuál es esa crisis que nos devasta y nos ciega? ¿Acaso aquellas palabras que pronunció en esa obra

5. $\mathrm{M}$, prefacio $\$ 4$.

6. EH, KSA VI 365 . 
nunca realizada que aún exige paternidad: Der Wille zur Macht? ¿El nihilismo? Tiene razón Barthes cuando enuncia el nuevo canon de la modernidad: «Ser moderno es saber qué es lo que ya no es posible» ${ }^{7}$. La emergencia de Nietzsche como pensador que define una época, un mundo, el destino de Occidente, acaso se empezó a gestar aún contra el mismo Nietzsche.

Los esfuerzos de muchos pensadores, entre ellos Heidegger, de ordenar la obra de Nietzsche, de interpretarla o descifrarla fueron decisivos para toda clase de malos entendidos. Quizá ahí se gestó ese dictum del filósofo de Turín. Quizá fue ahí donde el mismo Heidegger haya tenido la oportunidad de conformar en palabras lo que a comienzos de 1930, en el célebre ensayo La doctrina platónica de la verdad (Platons Lehre von der Wahrheit), Heidegger designa a Nietzsche como aquel pensador que lleva a su acabamiento la metafísica iniciada por Platón, en la medida en que, al invertir el platonismo, permanece él mismo dentro del horizonte del pensamiento que pretende invertir y, por ello, para Heidegger queda definido como «el platónico más desenfrenado de la historia de la metafísica occidental $»^{8}$. Heidegger, a partir de entonces, no dejará de establecer paralelos con la filosofía de Nietzsche y la metafísica platónica, de hecho podríamos decir que el pensador de Basilea será una suerte de hilo de Ariadna para su pensamiento a fin de pensar de manera radical la negatividad inherente al ser.

Aquí encuentran eco las palabras de Gerhard: «Quien busque la comprensión profunda de la existencia humana, el análisis puntual de los problemas filosóficos fundamentales, las cimas de la representación de sí mismo del hombre o simplemente la contribución de la filosofía a la modernidad, ya no puede evitar a Nietzsche. Es el clásico moderno por excelencia»" ¿Qué se dejó de leer en la obra Nietzscheana? ¿Qué es lo que lo convierte en el último metafísico o en el clásico de la modernidad? ¿Acaso la estructura oculta (borrada y por ello visible) que se transforma en uno de los significados del o de los mensajes Nietzscheanos? ¿No es acaso cierto que Nietzsche ha sido y es un símbolo por descifrar?

\section{HEIDEGGER, PENSADOR DE NIETZSCHE}

Una de las más grandes obras de Heidegger es la dedicada a Nietzsche. Todos sabemos que se trata de la lectura personal de Heidegger que recoge las lecciones de 1936 a 1940 en Friburgo y otros ensayos surgidos entre los años 1940 y 1946. No se trata de una lectura lineal, sino de una lectura fragmentada, a libro abierto, que permite establecer una relación inesperada, osada, arriesgada, diría, entre la letra y la consigna. Esta lectura, intencionada, es una prueba del quiebre interpretativo que hace Heidegger de Nietzsche. El contraste entre el enigma y la persuasión parece invertirse y nos liga a la orientación de una única vía donde se nos dice la última convicción o interpretación. Se trataría, entonces, de percibir una tensión entre la interpretación y la obra, entre la lectura y la verdad última.

7. R. Barthes, Lo obvio y lo obtuso. Imágenes, gestos, voces, Buenos Aires: Paidós, 1986, p. 236.

8. M. Heidegger, Zollikoner Seminare, ed. de M. Boss, Frankfurt a. M.: Klostermann, 1987, p. 182 (hay una extraordinaria traducción de A. Xolocotzi, México: Jitanjáfora, 2007).

9. V. Gerhard, Friedrich Nietzsche, München: Beck, ${ }^{2} 1995$, p. 9. 
La lectura de Heidegger me parece como aquella vieja idea de alguien que sólo tiene un libro en el que se cifra un mundo perdido y donde se reproduce en una escala ampliada una amenaza pura: en este sentido, la culminación de la metafísica pero no por ello su superación ${ }^{10}$.

Estamos en el tiempo de la «transición», en el lapso de lo que los comentaristas han llamando la «segunda época» o el «segundo Heidegger» ${ }^{11}$ o el Heidegger de la Kehre. ¿Qué se trataba de pensar? ¿Qué fue lo que cautivó al pensador de Todtnauberg para reflexionar en paralelo al pensamiento de Nietzsche ${ }^{12}$ ? Hay algo de dramatismo en la tesis que arriesgamos y es el hecho de que Heidegger reflexiona a partir de ese ser arrojado en el mundo y en el que el abandono ha hecho presa dejándolo en su no encuentro, en su extravío. La «muerte de Dios» es sólo el punto de inflexión, el pretexto recurrente que incita a pensar la radical soledad en la que se encuentra el hombre, la no justificación de su ser, de su existencia, esa «nada» como telón de fondo en el que, como escena de la vida, el hombre actúa arrojado ya no en el mundo sino arrojado de sí. Es éste el ápice de encuentro entre Heidegger y Nietzsche, pero quizá de la misma manera, éste fue el punto en el que se determinaron los rumbos diferentes.

En la Carta sobre el humanismo ${ }^{13}$, Heidegger nos dice que es necesario, inevitable, para dejar la metafísica, seguir hablando el lenguaje de la metafísica. Apuntar hacia lo que permanece impensado en la metafísica no es una crítica de la metafísica. Lo que Heidegger llama, en Nietzsche II, die Erinnerung in der Metaphysik, se opone a la mera y simple superación de la metafísica. Volver a recordar en ella no es la historia de la filosofía, en la cual el pasado se nos viene encima como una lluvia de informaciones, sino su Verwindung, la prueba de la metafísica como asunto del ser. Ahora de lo que se trata es de calar más hondo en su propio secreto, abrirse al secreto de que el ser se retira mientras se abre en el ente.

Si el pensamiento del filósofo de Aurora recoge y culmina, bajo un aspecto decisivo, la tradición que hasta ahora ha seguido el pensamiento en Occidente, entonces la discusión con Nietzsche se convierte automáticamente en una

10. Heidegger explica ahí, en el prefacio, que esta obra representa su «camino de pensamiento» desde 1930 hasta la Carta sobre el humanismo (1947), «en efecto, las dos pequeñas conferencias impresas durante ese lapso, 'La doctrina de Platón acerca de la verdad' (1942) y 'De la esencia de la verdad' (1943), ya habían sido escritas en los años 1930-1931». Cf. M. Heidegger, Nietzsche, 2 vols., Pfullingen: G. Neske, ahora en Gesamtausgabe, Frankfurt a. M.: Klostermann, 1975, en adelante Nietzsche I o Nietzsche II. Hay que tener en cuenta la magnífica traducción de Juan Luis Vermal, Barcelona: Destino, 2000, p. 16.

11. En este punto me parece muy relevante la obra de Ángel Xolocotzi, Fenomenología de la vida fáctica, Heidegger y su camino a Ser y tiempo, México: Universidad Iberoamericana y Plaza y Valdés, 2004. En este profundo libro Xolocotzi lleva a cabo una investigación sobre todos los elementos que demuestran la continuidad del pensamiento de Heidegger, sin rupturas, sin fallas, p. 13.

12. Nietzsche no ha sido para Heidegger un mero pretexto. Una de las tareas que Heidegger se impuso en Sein und Zeit fue la destrucción de la historia de la metafísica. Por ello no ha lugar a la extraña y ajena distinción entre las obras sistemáticas e históricas de Heidegger, entre destrucción y construcción; la historia de la metafísica es un elemento intrínseco del pensar heideggeriano, que es un pensar histórico, «haciendo historia». Estamos ante el tiempo de transición que lo condujo no a una nueva forma de pensar, ni a otro camino por el que el pensador de Todtnauberg intentara discurrir por los márgenes de la metafísica, sino a la preparación de ese «salto» que se define más bien como una preparación a la tarea del pensar, tarea enteramente nueva respecto de aquello que, de Heráclito a Nietzsche, se ha llamado filosofía o metafísica.

13. M. Heidegger, Über den Humanismus, Frankfurt a. M.: Klostermann, ${ }^{2} 1959$. 
discusión con el pensamiento occidental hasta el momento presente. La idea de Nietzsche, último resultado de la metafísica occidental, choca violentamente con los tópicos reinantes. Para Heidegger repensar la obra de Nietzsche significa repetir aquello de «cuanto más cerca temporalmente y casi contemporáneo nos es un pensador, tanto más largo es el camino hacia su pensamiento, tanto menos podemos ahorrarnos ese largo camino» ${ }^{14}$.

El error será reconocido cuando se ponga en movimiento una discusión con Nietzsche que sea al mismo tiempo una discusión dentro del espacio de la pregunta fundamental de la filosofía. Mientras tanto se puede citar sin embargo una frase de Nietzsche, proveniente de la época en que trabajaba en Der Wille zur Macht: «El pensamiento abstracto es para muchos un esfuerzo - para mí, en los días buenos, una fiesta y una embriaguez» ${ }^{15}$.

Al final del texto sobre Nietzsche en Holzwege, Heidegger escribe: «El pensamiento sólo empieza cuando hemos experimentado lo que la razón, tan magnificada desde hace siglos, es el adversario más obstinado del pensamiento» ${ }^{16}$. Esto significa que es posible pasar de la razón (Heidegger piensa esencialmente en el Discurso del método) al pensamiento, cuando se ha remontado lo suficiente río arriba. El trabajo de este remontarse, el «regreso río arriba», consiste en desintoxicarse del cálculo volviendo a su origen en el dominio del pensamiento, trabajo para el cual no basta, como hace Husserl, volver solamente a Descartes. El pensamiento de Nietzsche, para Heidegger, es la metafísica de nuestra época; esta metafísica piensa anticipadamente los rasgos fundamentales de esta época en que se da la lucha por el dominio de la tierra y en la que ella misma (la metafísica) toma parte.

Hay que reparar en que la controversia de Heidegger con Nietzsche tiene una meta próxima y una lejana: la meta próxima es la exposición de la unidad interna de la posición metafísica fundamental de Nietzsche, en cuanto posición fundamental de nuestra época; la meta lejana es el despliegue de la cuestión de si el combate supremo que librar sea entonces la lucha metafísica por el dominio de la tierra o si nuestro acontecer histórico pueda encontrar otro inicio que no sea ya metafísico ${ }^{17}$. «Sin embargo, lo decisivo sigue siendo con todo oír a Nietzsche mismo, preguntar con él, por él y a través de él, y eso quiere decir: preguntar al mismo tiempo contra él, pero en favor de la única causa, la causa común y más íntima de la filosofía occidental» ${ }^{18}$.

14. Nietzsche I, prefacio. Lo que postula Heidegger es que nos abramos a lo pensado por cada pensador como algo único, irrepetible e inagotable, de tal modo que irrumpa en nosotros lo no pensado en su pensamiento. Lo no-pensado sólo existe como no-pensado. Cuanto más original es un pensar, tanto más rico y pletórico será su fondo no-pensado. Abrirse a un pensador, salirle al encuentro es destacar lo que tiene de grande y engrandecerlo aún más, lo cual significa que interpretar es a la vez completar. Por el contrario, la postura fundamentalmente negativa comporta un empequeñecimiento de lo que hay de grande en un pensador, aunque se asegure, de paso, que fue «un gran filósofo». «Tales elogios 'desde abajo' son en realidad ofensas». Cf. M. Heidegger, Was heißt Denken, Tübingen, 1953, pp. 68-73.

15. Nietzsche I, p. 14. Asimismo, cf. Conferencias y artículos, Barcelona: Serbal, 1994, los capítulos «Superación de la metafísica», «¿Quién es el Zaratustra de Nietzsche? y «¿̨ué quiere decir pensar?».

16. M. Heidegger, Holzwege, Frankfurt a. M.: Klostermann, ${ }^{3} 1957$, p. 231.

17. Nietzsche II, pp. 261 ss.

18. Nietzsche I, p. 33. 


\section{EN CAMINO HACIA EL NIHILISMO Y LA VOLUNTAD DE PODER}

Sé que la lectura que hace Heidegger de Nietzsche ha definido nuestra manera de leer al propio Nietzsche. Ha definido, habría que decir, lo que está ya planteado en la que muchos pensamos como la lectura de Nietzsche como modelo de lo que quiere decir leer filosofía y perderse en ella. Ha esculpido el gran modelo de lector de filosofía, ya no el que lee para descifrar, ya no el que desconfía del sentido de los signos, el que sospecha de la letra, el que se enfrenta a enigmas, sino el que lee para creer. Heidegger en esto es incuestionable.

Tenemos que recordar que el primer encuentro de Heidegger con Nietzsche se lleva a cabo ya en Sein und Zeit, justo en aquella alusión, en el parágrafo 76, cuando se refiere a la segunda de las Consideraciones intempestivas (Unzeitgemässe Betrachtungen) para recordar la triple práctica de la historia que Nietzsche discurre: la monumental, la anticuaria y la crítica ${ }^{19}$; la consideración ahí es ambigua y tardará todavía un poco hasta que la voluntad de apropiarse del pensamiento de Nietzsche se haga presente. Es probable que no haya sido hasta las lecciones de 1936 en Friburgo cuando se fraguara el primer encuentro de Heidegger con el «loco de Turín».

Tal vez, a modo de hipótesis, podemos aventurar que el concepto metafísico de nihilismo peculiar de Nietzsche pudo haber tenido impacto en el Heidegger de juventud, tal y como lo había tenido la lectura de Duns Scoto. En Sein und Zeit y en la lección Was ist Metaphysik? Heidegger concede a la noción de la «nada» una categoría y, sobre todo, un enfoque que representaba una novedad en la historia de la filosofía ${ }^{20}$. En la tradición metafísica occidental la «nada» era simplemente «nadanadería», nichtiges Nichts, comentaría Heidegger, la pura negación del ser. Heidegger, para recuperar el ser perdido en el ente y expresar su esencial carácter huidizo, comienza por situar, establecer y colocar la ecuación hegeliana de ser $=$ nada $^{21}$.

La relativamente temprana preocupación de Heidegger por la nada pudo haber despertado su creciente interés por el nihilismo de Nietzsche. El hecho es que desde la lección de 1940 Der europäische Nihilismus, Heidegger vuelve una y otra vez sobre esta expresión equívoca. Nietzsche había sido el primer pensador que la empleó con plena conciencia de su alcance metafísico y en un sentido que en su intención equivale a «nihilismo occidental». Heidegger recuerda que la antigua metafísica entendía la «nada» en el sentido de lo que no es. Según el mismo Heidegger la «nada» se nos descubriría ahora como perteneciente no al ser en cuanto tal sino al mismo ser del ente.

En razón de lo anterior, la nada, en Was ist Metaphysik?, se mostraría o «develaría» como fundamento de la negación y no al revés. La historia de este

19. Cf. F. Volpi, El Nihilismo, cit., pp. 87-88. Asimismo, cf. G. Vattimo, Introducción a Nietzsche, Barcelona: Gedisa, 1987, p. 80. Ahí hace referencia a la atención que Heidegger prestó a Nietzsche y cita el parágrafo 76 de Ser y tiempo.

20. Desde luego, por lo menos hasta los idealistas alemanes y dejando aparte a los místicos, sin descartar los enfoques que había llevado a cabo Bergson y, un poco más lejos en el tiempo, Leibniz.

21. Al efecto de este comentario de la obra de Heidegger, no creo necesario recordar la confusión que se creó en torno a esta "nada" que desorientó a los mejores intérpretes y fue ocasión de que Heidegger quedara catalogado como pensador nihilista. Afirmaciones a las que Heidegger salió al paso en la Carta sobre el humanismo (1947), en el epílogo (1943) y en el prólogo a Was ist Metaphysik? de 1949 
pseudoconcepto está ligada a la historia misma del ser para Heidegger. El ser, visto desde el ente, es nada. Bajo esta especie sub specie nibili se aborda el ser, cambiando el sentido de los términos. Ser y nada son lo mismo. Heidegger no quiere decir que el ser no es nada, en el sentido en que decir ser o no decir nada sería lo mismo. Quiere decir que el ser no es nada de ente; una vez más se trata de una exhortación a pensar la diferencia entre el ser y el ente. La Nada adquiere caracteres absolutos en la Lógica de Hegel. Aunque sería mejor decir que en Hegel el absoluto presenta una ausencia total de caracteres. ¿Cuál es, entonces, la razón por la cual el Ser ha de ser conceptuado como ese «vacío perfecto», es decir, por qué el ser puro es vacío puro y se identifica o encuentra su identidad perfecta con la Nada, la ausencia de determinaciones y de contenidos? ¿Por qué, en suma, el ser puro es idéntico a la nada pura?

Nietzsche ha sido el primer pensador que ha tomado conciencia del nihilismo y ha intentado pensarlo. Más aún, como dice A. de Waelhens, «Kierkegaard es el representante de un nihilismo aún lleno de ilusiones; Nietzsche, el de un nihilismo consciente de sí, pero que se esfuerza por superarse» ${ }^{22}$. Nietzsche entiende por nihilismo un acontecimiento histórico que da carácter al siglo XIX e ilumina un futuro incierto, pero que viene preparándose siglos atrás; Nietzsche lo resume en la estridente fórmula "Dios ha muerto» ${ }^{23}$.

En su estudio Nietzsches Wort «Gott ist tot», Heidegger comienza por denunciar la confusión sobre el significado de la muerte de Dios como nihilismo, pues no basta con profesar una metafísica, ni siquiera la fe cristiana, para considerarse fuera del nihilismo. Como, a la inversa, el hecho de que alguien intente esclarecer la nada y su esencia no autoriza a calificarlo de nihilista. El nihilismo del que se ocupa Nietzsche no es una doctrina sino un «movimiento histórico», un acontecimiento decisivo en la historia de los pueblos occidentales; es el movimiento fundamental de la historia de Occidente en el que la negatividad se convierte en el signo esencial que distingue a la modernidad, al menos su lado nocturnal. «Pertenece - dice Heidegger- a la esencia de este extrañísimo huésped el no poder conocer su propio origen». Lo más frecuente es considerar el nihilismo como una secuela de la descristianización occidental, del librepensamiento o del ateísmo, pero ya advertía Nietzsche en el pasaje del «hombre loco» que la frase «Dios ha muerto» nada tenía que ver con el ateísmo, es algo mucho más sutil y mucho más tremendo:

22. A. De Waelhens, La filosofía de Martin Heidegger, Universidad Autónoma de Puebla, ${ }^{2} 1986$, pp. 303-304.

23. Esta formulación del nihilismo es en extremo ambigua. Lo cierto es que la noción misma de nihilismo está aquejada de la misma ambigüedad. Tal parece que algunos conceptos en la filosofía no funcionan sólo como metáforas sino como articulaciones de la forma, nudos que relacionan los niveles del relato y cumplen en la narración una compleja función constructiva. Así el nihilismo, que parecía ser un síntoma de la época que circulaba entre la imaginación y lo real, entre el miedo y la locura, es justo el martillo de Nietzsche; desde entonces su sola enunciación es como el nombre de un arcano maligno, su sola mención originó una suerte de doctrina sobre la pérdida y el vacío, la experimentación de la «nada», esa experiencia más originaria, aquella a la que se accede mediante un estado de ánimo fundamental: la angustia. Ahí, en esa trama todos podemos sentirnos llamados y nombrados por ella. Vuelvo a remitir al estudio de Franco Volpi, extraordinario por múltiples razones, más aún cuanto que en ese estudio Volpi hace un recuento de todos los matices que ese concepto encierra y que nos ilumina, El Nibilismo, cit. 
En realidad, nosotros filósofos, los «espíritus libres», ante la noticia de que el «viejo Dios ha muerto", nos sentimos como iluminados por una nueva aurora: ante ella nuestro corazón rebosa de agradecimiento, asombro, presentimiento, expectación - por fin nuestro horizonte se encuentra nuevamente despejado y, aun cuando no sea luminoso, finalmente podrán salir a la mar de nuevo nuestros barcos, zarpar hacia cualquier peligro; cualquier empresa, por aventurada que sea, le está nuevamente permitida a los que buscan el conocimiento; el mar, nuestro mar está nuevamente abierto; quizá nunca había existido un mar tan abierto ${ }^{24}$.

Para Heidegger, particularmente, el «Dios» que ha muerto no es, pensado esencialmente, sino el mundo ideal suprasensible procedente de Platón, que ha sido norma para Occidente. La metafísica sería el suelo y ámbito donde tiene lugar el acontecimiento llamado nihilismo, metafísica entendida como concepción general del ente bajo el esquema platónico del mundo sensible y suprasensible, el primero regido por el segundo. La desintegración de lo suprasensible en sus múltiples formas: ideas, Dios, ley moral, autoridad de la razón, el progreso, la felicidad de los más, la cultura, la civilización, en fin, todo concebido como un acontecimiento metafísico.

Por ignorar este enraizamiento metafísico y, por tanto, su remoto origen y larga pervivencia, se cae en la ingenuidad de combatir aquellos fenómenos que no son más que derivaciones del nihilismo, confundiéndolos con éste o con sus causas; así, la prepotencia de la técnica como culpable de la «situación espiritual de nuestro tiempo». Nietzsche, para el pensador de la Selva Negra, ha sido el primero que ha tomado conciencia del nihilismo y ha intentado pensarlo. Pero, se pregunta Heidegger si Nietzsche realmente comprendió su esencia. En una nota de 1887 recogida en Der Wille Zur Macht Nietzsche se interrogaba qué significa nihilismo. Y respondía: que los más altos valores se desvalorizan. Nietzsche aquí subraya esas palabras y añade otra aclaración: «Falta el fin; falta la respuesta al porqué». En la era del nihilismo los valores supremos, todo aquello que regía y determinaba la vida humana ha perdido vigencia. Y la ha perdido porque ha surgido la sospecha de que el mundo ideal no puede plasmarse en el real. La obligatoriedad de los más altos valores se hace problemática. Para Nietzsche se trata de una ley histórica, la «lógica interna» de la historia occidental. Porque su superación es casi imposible por el surgimiento de nuevos dioses: la felicidad terrena, el socialismo, la música de Wagner, dioses, siempre nuevos dioses. Con ello lejos de superarse, el nihilismo queda agudizado; es lo que Nietzsche llama «nihilismo imperfecto».

En su acercamiento al pensamiento Nietzscheano, Heidegger se explica así: los lugares vacíos que conserva el nihilismo imperfecto no son sino el reino ideal de lo suprasensible; el nihilismo perfecto debe eliminar el lugar mismo, lo suprasensible como región y reino, para colocar los nuevos valores en otro lugar y así instaurar un nuevo principio de valores y superar de verdad el nihilismo. Hay que sustituir el mundo de lo suprasensible, ya exangüe, por algo que sea más vivo; el nihilismo perfecto, clásico — de ambos modos lo denomina Nietzsche- buscará un ideal que sea «el ideal más exuberante».

Nietzsche, piensa Heidegger, había interpretado la esencia del nihilismo desde la perspectiva del valor, y la aclaración de lo que Nietzsche piensa bajo la

24. KSA III 573. 
etiqueta de valor es la clave para entender su «metafísica». Que la palabra «valor» sea esencial en la doctrina de la voluntad de poder, le parece a Heidegger que Nietzsche lo da a entender en el subtítulo de la obra que había de contener esa doctrina: «Ensayo de una transmutación de todos los valores». En una nota de 1887-1888 recogida en Der Wille zur Macht Nietzsche había propuesto la siguiente definición de valor: «el punto de vista del valor es el punto de vista de las condiciones de conservación y crecimiento respecto de estructuras complejas - de duración relativa - de la vida dentro del devenir» ${ }^{25}$.

Como punto de vista que es, el valor está determinado por y para un «ver», un ver que es representar y, como tal, implica como ingrediente esencial la tendencia o apetito, como había señalado Leibniz (el appetitus, concomitante de la perceptio). El valor es punto de vista y punto de vista es el hecho de ser todo ente representativo-apetitivo. Es decir, valor significa para Nietzsche tanto como «condición de la vida», algo que se requiere para que la vida sea vida. Vida en Nietzsche es lo mismo que ente; vida es cada ente y el conjunto de los entes. En este sentido, los valores son «condiciones de conservación y crecimiento de la vida». De estas dos notas la decisiva es la segunda: la superación (Steigerung über sich hinaus). Es el valor como condición de la vida el que tiene que concebirse como aquello que excita y fomenta el incremento de la vida; sólo lo que eleva la vida tiene valor o, más exactamente, es un valor ${ }^{26}$.

Las condiciones que apuntan a la mera conservación se convierten en impedimentos para la elevación de la vida y son, estrictamente hablando, disvalores, que es lo que eran los «supremos valores tradicionales». Esto es lo que Nietzsche exige y demanda: una «transmutación de todos los valores anteriores y una nueva posición de valores» ${ }^{27}$. La vida transcurre dentro del ámbito del devenir (Werden), pero el devenir para Nietzsche es en el fondo lo mismo que voluntad de poder. «Voluntad de poder, devenir, vida y ser en el más amplio sentido significan en el lenguaje de Nietzsche lo mismo $»^{28}$, dice Heidegger.

En el seno del devenir se configura la vida, lo viviente, en los respectivos centros y estructuras de poder: arte, Estado, religión, ciencia, sociedad. La voluntad de poder es, pues, la que determina todos los puntos de vista, todos los centros de dominio y, por tanto, todos los valores; la voluntad de poder es el origen, a la vez, de la necesidad y de la posibilidad de la posición de valores; es ella la que los necesita y los hace posibles. De ahí las palabras de Nietzsche: «Los valores y su mutación están en relación con el incremento del poder del que pone los valores ${ }^{29}$.

¿Es entonces Nietzsche un consumador de la metafísica? ¿Es verdaderamente Nietzsche quien lleva a su culminación el destino de Occidente en el sentido aludido por Heidegger del olvido del ser y por tanto, del final de la metafísica? ¿Son ciertas aquellas palabras que el pensador de Das Ding imputó a Nietzsche cuando afirma que «[...] el pensamiento de Nietzsche, tal y como ha sido hasta

25. «Der Gesichtspunkt des 'Wertes' ist der Gesichtspunkt von Erhaltungs-, Steigerungs-Bedingungen in Hinsicht auf complexe Gebilde von relativer Dauer des Lebens innerhalb des Werdens».

26. Nietzsche I, p. 394.

27. Cf. ibid., cap. 3.

28. Ibid., p. 302.

29. Cf. M. Heidegger, Holzwege, cit., pp. 201-213. 
ahora, es metafísica, y el pensamiento de Nietzsche representa probablemente su cumplimiento» ${ }^{30}$ ?

«Al pensamiento Nietzscheano de la voluntad de poder lo denominamos su pensamiento único. Con ello queda dicho al mismo tiempo que el otro pensamiento de Nietzsche, el del eterno retorno de lo mismo, está necesariamente incluido en el de voluntad de poder ${ }^{31}$. El título voluntad de poder es un término fundamental de la filosofía de Nietzsche, de lo que para Heidegger es su metafísica, que es metafísica de la voluntad de poder. Nietzsche habla por primera vez de la voluntad de poder en un contexto revelador: en la segunda parte de Also sprach Zarathustra, que apareció en 1883, un año después de Die fröhliche Wissenchaft, donde escribió:

Allí donde encontré algo vivo, encontré voluntad de poder. Querer es querer-serseñor; también en la voluntad de servicio hay voluntad de poder, no sólo porque el servidor aspire a dejar su condición para convertirse en señor; también ser-servidor es querer-ser-señor ${ }^{32}$.

Querer, explica Heidegger, no es un desear, simple aspiración, tendencia a algo, sino que incluye en sí mandar. Quien manda es señor en cuanto dispone con su saber sobre las posibilidades de obrar; en el mandato se manda la realización de lo dispuesto y planeado. En el mandato obedece el que manda, no sólo el que ejecuta; obedece a ese disponer y poder disponer, y así se obedece a sí mismo; mandar es superarse (obedecerse) a sí mismo y es más fácil que obedecer; sólo a quien no es capaz de obedecerse a sí mismo hay que mandarle. De igual forma el «poder» de la voluntad de poder no es sino el modo como la voluntad se quiere a sí misma: un mandato, un mandar; al mandar, la voluntad es una misma cosa con lo mandado, con lo querido.

La esencia de la voluntad de poder es la misma esencia del querer: querer es voluntad de poder. Heidegger piensa que la voluntad de poder se revela en su verdadera realidad como el fundamento y ámbito de la posición de valores. La voluntad de poder y la posición de valores son la lógica consecuencia, la «consumación de la metafísica», ante todo de la moderna. Esta última se afana tras lo incondicionalmente indubitable, lo cierto, la certeza, firmum et mansurum quid stabilire, en expresión de Descartes. Lo permanente, lo constantemente presente es desde antiguo el hypokeimenon, el sub-jectum, lo que subyace, y modernamente la verdad como certeza, el ego cogito, la subjetividad de la conciencia como certeza. Sólo que ya con Leibniz el eidos (forma del ente) se había transformado en perceptio, acompañada del appetitus. En Nietzsche el appetitus de la perceptio, dice Heidegger, se metamorfosea en voluntad de poder. La ousia o entidad del ente, el sub-jectum se había transmutado en la Edad Moderna en «subjetividad» de la conciencia, pero esta subjetividad es ahora, con Nietzsche, cuando muestra su verdadero rostro, lo que en el fondo era: voluntad de querer,

30. M. Heidegger, "Wer ist Nietzsches Zarathustra?», en Vorträge und Aufsätze, Pfullingen: Neske, 1954, p. 80.

31. Nietzsche I, p. 389

32. Citado en M. Heidegger, «La frase de Nietzsche 'Dios ha muerto'», en Caminos de bosque, trad. de H. Cortés y A. Leyte, Madrid: Alianza, 1996, pp. 190-240. 
el querer del querer. «Querer — dice Nietzsche- es tanto como querer llegar a ser más fuerte, querer crecer, y además querer los medios» ${ }^{33}$.

Nietzsche, según Heidegger, desarrolla la «lógica interna» de esta concepción. La verdad y la certeza ${ }^{34}$ son en su última esencia valores, y valores puestos por la voluntad de poder, es ella quien debe poner las condiciones de mantenimiento y conservación de sí misma, por tanto, de la aseguración de sí misma y del ente. El ente, que está presente en la representación no queda asegurado sino por la seguridad de tenerlo por verdadero por la certeza; luego el fundamento último de la verdad y de la certeza es la voluntad de poder; verdad y certeza son valores exigidos y puestos por la voluntad de poder. La doctrina de Nietzsche sobre la voluntad de poder como esencia de toda realidad es la culminación de la metafísica moderna de la subjetividad y, piensa Heidegger, el paso al nihilismo de la técnica.

El problema principal es la posible superación del concepto de «representación"; es decir, el intento de ver lo que hay detrás de este concepto en el tejido de la vida. Y ello implica la superación del subjetivismo de la filosofía moderna. La filosofía moderna ha producido desde ese «gesto soberano», como le llamó Foucault al gesto de Descartes, el concepto de un sujeto universal que condiciona todos los objetos: el cogito ergo sum o la síntesis pura kantiana en el sujeto: la unidad de la apercepción; estos son dos ejemplos de ello.

\section{HACIA LA CRÍTICA NIETZSCHEANA DE HEIDEGGER}

Heidegger ha creído encontrar en Nietzsche la aspiración a superar el nihilismo con un nuevo principio de valores, la voluntad, pero justo por ello el pensador de Basilea, a los ojos de Heidegger, permanece ligado a una metafísica de los valores. La metafísica de la voluntad de poder pretendía ser la superación del nihilismo, y lo es, si concebimos el nihilismo simplemente como desvalorización de los valores precedentes y a la voluntad de poder como un nuevo principio de valoración. Pero ¿̇sería una metafísica si lo que Nietzsche propone por nihilismo es la ausencia del ser, la ausencia del sentido, de la causalidad, del horizonte donde todo se forma con un ritmo y sus pausas? Es cierto que el pensar axiológico es el mayor enemigo del ser, porque el valor «no le deja ser al ser», como dice Heidegger, de tal suerte que la pretendida superación del nihilismo no sería sino su consumación.

La metafísica de Platón no es menos nihilista que la metafísica de Nietzsche. En aquel queda oculto el nihilismo, en éste se hace patente, dice Heidegger. La metafísica de Nietzsche, por estar vinculada a la representación, es esencialmente una filosofía de la subjetividad, puede decirse incluso que es la forma consumada de la filosofía del sujeto, destino de los tiempos modernos. Su filosofía es la máxima expresión del nihilismo. El verdadero error de Nietzsche, según Heidegger, procede de su desconocimiento del nihilismo. Como consecuencia de esto, todos los rasgos de su filosofía se inscriben en el ámbito del mundo contemporáneo y confirman el nihilismo metafísico inherente a este mundo, en

33. Citado en M. Heidegger, «La frase de Nietzsche 'Dios ha muerto'», op. cit. (Voluntad de Poder, $\mathbb{6} 675$, del año 1887/1888).

34. La certeza no es sino la seguridad de tener algo por verdadero. 
lugar de superarlo. No son más que expresiones metafísicas de la dominación ejercida por la humanidad de este mundo, instalada en el abandono del ser.

Si la metafísica de Nietzsche no sólo interpreta al ser como un valor desde el ente en el sentido de la voluntad de poder, si piensa además a la voluntad de poder como el principio de una nueva posición de valores y comprende a ésta como una superación del nihilismo, entonces en ese querer superar se expresa el más extremo quedar enredada de la metafísica en lo impropio del nihilismo, de manera tal que con ese quedar enredada se cierra el paso a su propia esencia y así, en la forma de una superación del nihilismo le da a éste, sólo entonces, la eficiencia de su inesencia desencadenada ${ }^{35}$.

La ausencia del ser, entendida ésta como olvido del ser, no le ha acontecido a la metafísica por casualidad ni por descuido ni por error; es propio del ser quedar impensado, solaparse y esconderse dentro de su verdad, quedar vedado y velado mientras se revela, y ocultar su misma ocultación; la patentización (desocultación) entraña ocultación, ello es la esencia del misterio.

La metafísica es lo impensado del ser, precisamente porque se funda en el misterio del ser. La metafísica sería entonces «destino», el destino del ser. Metafísica es una «época de la historia del ser». El verdadero nihilismo no es la volatilización del ente, sino del ser; el día que sepamos escuchar el nihilismo en este tono y bajo estas profundas visiones reconoceremos que «ni las perspectivas económicas, ni las políticas, ni las sociológicas, ni las técnicas y científicas, ni siquiera las metafísicas y religiosas bastan para pensar lo que está pasando en esta edad mundial» ${ }^{36}$. Eso que nos falta por pensar no es algún trasfondo inaccesible, sino algo que está ahí, lo más próximo y que por lo mismo se nos pasa siempre por alto: el $\operatorname{ser}^{37}$.

La esencia del nihilismo no reviste apariencia catastrófica, no se presenta con caracteres destructivos y negativos en el ámbito humano, porque la esencia del nihilismo no es cosa del hombre y no le afecta directamente a él. Es cosa del ser y, por eso mismo, afecta a la esencia del hombre. Según esto, Nietzsche no logró superar el nihilismo porque no penetró hasta su esencia. Pero tampoco lo hizo Heidegger. A fin de remontarse auténticamente por encima del nihilismo, para comprender la esencia del ser en su movimiento de presencia y de ocultación, habría que comprender que lo que se esencializa en el nihilismo es el «morar-en-ausencia» del ser en cuanto tal. Este morar-en-ausencia consiste en la ocultación que se lleva a cabo a través de la historia del ser, a partir del ser mismo. Es la inextirpable presencia de la «nada» en el ser. Así la incomprensión de la esencia del nihilismo conduce, en definitiva, a la incomprensión de la nada, del nibil: «Puede que la esencia del nihilismo resida en el hecho de que no se toma en serio la cuestión de la nada. En realidad, se rehúsa desarrollar esta cuestión y se defiende obstinadamente el esquema de una alternativa asimilada desde hace mucho tiempo» ${ }^{38}$.

Sin duda, Heidegger pretende trascender el nihilismo por medio de una «superación de la metafísica», pero isignifica esto el rechazo y la radical negación

35. Nietzsche II, p. 305 Tomamos la traducción de Juan Luis Vermal que es excelente.

36. M. Heidegger, Holzwege, cit., pp. 244-246.

37. Ibid.

38. Nietzsche II, p. 48. 
de la metafísica? El problema presentado en estos términos saldría al encuentro de la complejidad de su pensamiento y del equívoco deliberadamente mantenido y relacionado con la naturaleza misma del objeto tratado. Entregado al pensamiento del ser, Heidegger piensa necesariamente dentro del ámbito de la metafísica y como «metafísico». La superación de la metafísica debe ser entendida como el reconocimiento de su dignidad irremplazable; como una apropiación de aquello que se explica en Contribución a la cuestión del ser. Aquí el equívoco se aclara, al tiempo que pone en evidencia su carácter de inevitable.

En este texto, la relación del ser con el ente, su «producción» como destino en el interior de la historia de la metafísica, postula la noción de trascendencia, utilizada ya en Sein und Zeit y reemplazada por otra terminología. La noción «destino de la trascendencia» es utilizada para salvar la metafísica y mostrar cómo en ella la «no-verdad» forma parte integrante de la verdad. La relación verdad no-verdad constituye también uno de los temas de La esencia de la verdad (1930), en donde decía que, por una parte, si la «nada» reinaba en la esencia del nihilismo y en el ser se inscribía la esencia de la nada; y si, por otra parte, el ser era destino de la trascendencia, entonces la esencia de la metafísica se nos revelaba como el lugar de la esencia del nihilismo ${ }^{39}$.

Nietzsche en sus Fragmentos póstumos escribió:

El nihilismo aparece ahora no porque el disgusto por la existencia sea mayor que antes, sino porque nos hemos vuelto desconfiados en general frente a un «sentido» en el mal, incluso en la existencia. Se ha hundido una interpretación pero, puesto que valía como la interpretación, parece como si no hubiese ningún sentido en absoluto en la existencia, como si todo fuera en vano. Queda por demostrar que este «ien vano!» es el carácter de nuestro actual nihilismo. La sospecha sobre nuestras anteriores valoraciones culmina en la cuestión: «¿No son todos los 'valores' un señuelo con el que se alarga la comedia pero sin por ello aproximarse a ningún desenlace?». La duración, con un «en vano» sin meta ni fin, es el pensamiento más paralizado, especialmente cuando se concibe que se haya sido engañado y, no obstante, se es impotente para evitar ser engañado. Meditemos este pensamiento en su forma más terrible: la existencia tal como es: sin sentido y sin meta pero repitiéndose inevitablemente, sin final en la nada: «el eterno retorno». Ésta es la forma más extrema del nihilismo: ila nada (el «sinsentido») eterna! ${ }^{40}$.

De igual manera, el epígrafe con el que comenzamos este ensayo habla por sí solo: «El pesimismo moderno es una expresión de la inutilidad del mundo moderno - no del mundo y de la existencia ${ }^{41}$. Hay pues algo que nos parece injusto en la postura de Heidegger hacia Nietzsche: el nihilismo de la época moderna puede ser definido como una tesis sobre el carácter relativo y ficticio de todos los valores. Cuando la validez objetiva del deber ser desaparece, la destrucción puede ser una mera consecuencia de su desaparición pero quizá no, si como nihilista consecuente no se está dispuesto a hacer de esta destrucción un

39. Cf. M. Heidegger, «De la esencia de la verdad», en Hitos, ed. de H. Cortés y A. Leyte, Madrid: Alianza, 2000, pp. 151-171.

40. F. Nietzsche, El nibilismo: escritos póstumos, Barcelona: Península, 2000, «El nihilismo europeo. Lenzer Heide, el 10 de junio de 1887», fragmentos 4-5, pp. 45-46.

41. El nibilismo, op. cit., frag. 1[194], p. 27. 
nuevo deber ser. No hay necesariamente, como cree Heidegger, una relación lógica entre nihilismo y destrucción y la consecuente puesta en juego del deber ser como verdad irrefutable de todos los valores, sino sólo una lucha por imponer la única y verdadera moral o valor. En El Anticristo Nietzsche había expresado su apreciación sobre la transvaloración de los valores:

Para poder decir no a todo lo que representa en la tierra el movimiento ascendente de la vida, la buenaventura, el poder, la belleza y la autoafirmación, el instinto del resentimiento, convertido en genio, tuvo que inventarse otro mundo, desde el cual toda esta afirmación de vida se observara como algo malo y despreciable ${ }^{42}$

Este pensamiento quiere ubicar el origen del nihilismo, con lo cual Occidente se convierte en una historia del nihilismo: «Si el eje gravitacional de la vida no se ubica en la vida misma, sino en el más allá — en la nada, a la vida se le arrebata propiamente este eje» ${ }^{43}$. Más aún:

[...] los valores supremos se revelan decadentes, mas no por efecto del desgaste sino porque desde su origen niegan la vida, manifestando en esta época la «lógica de la decadencia» por la cual la «voluntad de verdad» [Wille zur Wahrheit], comprendida como una voluntad tendente hacia Dios [Wille zum Gott], hacia un mundo verdadero en el más allá, se muestra como lo que realmente es: una «voluntad hacia la nada» [Wille zum Nichts] ${ }^{44}$.

Heidegger proponía que nos abriéramos a lo pensado por cada pensador como algo único, irrepetible e inagotable, de tal forma que pudiera irrumpir en nosotros lo no pensado en su pensamiento. Lo no-pensado es aquello que sólo existe como no-pensado. Cuanto más original es un pensar, tanto más rico y pletórico será su fondo no-pensado. Hay que conducir nuestra comprensión hacia algo distinto, a esos espacios ocultos de la metafísica: hacia «lo no pensado» y «lo no dicho", que significan en Heidegger el rechazo positivo a dejarse decir y pensar. Este es el hilo conductor de Heidegger de principio a fin de su búsqueda de «lo no dicho» y «lo no pensado» en la metafísica. Pero hierra cuando interpreta a Nietzsche. Es el exceso y no la falta lo que evitó que se produjera el aparecer de lo que no se muestra en el pensamiento Nietzscheano. Estoy persuadido de que con Nietzsche se inaugura un nuevo pensar, justo ese del cual Heidegger es deudor, un nuevo pensar, como ha señalado Crescenciano Grave: «Nietzsche es así un pensador cuya posición metafísica fundamental compromete a la totalidad de la filosofía y, por lo mismo, se vuelve punto de inflexión que permite transitar más allá de la metafísica misma» ${ }^{45}$. Y añade:

¿Cómo ve Heidegger la transición hacia el otro inicio del pensar desde la consumación de la metafísica? Esta transición no es un progreso pero tampoco un retroceso:

42. AC $\$ 24$, KSA VI 182

43. AC $\$ 43$, KSA VI 217.

44. L. Laiseca, El nibilismo europeo, el nibilismo de la moral y la tragedia anticristiana en Nietzsche, Buenos Aires: Biblos, 2001, pp. 29-30.

45. C. Grave, Nietzsche y Heidegger. ¿El último metafísico y el nuevo inicio del pensar?, México: UNAM, 2002, p. 74. 
es un iniciar desde la tradición de las respuestas metafísicas que han entregado la responsabilidad del ente a los que preguntan; es prepararse, sin responder, como pensar que escucha al ser y vuelve al hombre dispuesto a guardar la verdad del $\operatorname{ser}^{46}$.

Nietzsche, según Heidegger, desarrolla la «lógica interna» de esta concepción. La verdad y la certeza ${ }^{47}$ son en su última esencia valores, y valores puestos por la voluntad de poder, es ella quien debe poner las condiciones de mantenimiento y conservación de sí misma, por tanto, de la aseguración de sí misma y del ente. No obstante, y en esto coincido con Paulina Rivero, «no existe, pues, algo así como la verdad sobre un hecho, sino ciertos sentidos y ciertas interpretaciones del mismo que se suceden a lo largo de la historia: toda 'verdad' no es más que una interpretación hecha desde una cierta voluntad de poder» ${ }^{48}$.

En la trama del conocimiento no existen sujetos puros y absolutos como se ha pretendido, ni como sustancia ni como forma, ni como síntesis. En sí, el sujeto no es nada. Por eso puede escribir el maestro de Basilea: «el problema de los valores es más fundamental que el problema de la certeza; este último sólo alcanza sentido bajo el presupuesto de que el problema del valor ha sido solucionado» ${ }^{49}$. Y es claro porque el sujeto es un concepto dudoso, porque en todo caso podemos resolver el sujeto en términos de objeto, como bien lo vio Foucault ${ }^{50}$ :

[...] en mi opinión, es el mejor, más eficaz y actual de los modelos que tenemos a mano para llevar a cabo las investigaciones que propongo. Creo que en Nietzsche se encuentra un tipo de discurso en el que se hace el análisis histórico de la formación misma del sujeto, el análisis histórico del nacimiento de un cierto tipo de saber, sin admitir jamás la preexistencia de un sujeto de conocimiento... ${ }^{51}$.

La experiencia de la desvalorización de todos los valores tradicionales (entendidos éstos como el mundo suprasensible platónico) culmina en la conciencia de que "Dios ha muerto", de que los fines, metas e ideales de la precedente metafísica se han hecho ineficaces, han quedado inertes. No se trata entonces de pasar de las categorías fuertes a las categorías débiles como señala Vattimo ${ }^{52}$, sino de comprender que este paso se ha dado sólo mediante el acto de la Verwindung, como la forma en la que ha de ser tratada la metafísica, como una época del olvido del ser, como algo inscrito en el destino del ser y de su olvido mismo y no como «superación» de la metafísica. Su «superación» no es un acto de la voluntad humana, no es un acontecimiento sin más, es lo impuesto, lo que ha lugar, y sólo podremos alcanzar otra forma, otra suerte de estado en cuanto entendamos que

46. Ibid.

47. La certeza no es sino la seguridad de tener algo por verdadero.

48. P. Rivero Weber, «Las notas de la verdad en la hermenéutica Nietzscheana», en Cuestiones hermenéuticas, de Nietzsche a Gadamer, México: UNAM, 2006, p. 22.

49. Citado en M. Heidegger, "La frase de Nietzsche 'Dios ha muerto'», en Caminos de bosque, op. cit. (Voluntad de Poder, $\$ 588$, del año 1887/1888).

50. M. Foucault, Las palabras y las cosas. Una arqueología de las ciencias humanas, México: Siglo XXI, 1997. Foucault analizó el desarrollo, entre los siglos XVIII y XIX, de las ciencias humanas: economía, ciencia natural, lingüística; y las estudió como conocimientos «objetivos» en relación con un «sujeto» (el Hombre) que — dice allí- es apenas «una formación discursiva destinada a desaparecer».

51. Ibid., p. 254.

52. Cf. G. Vattimo, El fin de la modernidad, Barcelona: Gedisa, 1994, pp. 151 ss. Cf. también El pensamiento débil, Madrid: Cátedra, 1990, pp. 18-42, en donde se refiere a la Verwindung. 
la metafísica tiene que ser comprendida como Verwindung, «una convalecencia de la enfermedad de la modernidad», como nos lo recuerda Laura Laiseca ${ }^{53}$.

La tarea consiste en «recuperarnos» de ella a través de una «re-signación» (una forma de dotar de nuevo sentido), de una grafía a otra, de comprender que las consecuencias de la metafísica de la modernidad, que el proyecto mismo de la modernidad es un destino. Apoderarse, apropiarse, ajustarse, asumir ese mal, ese pasado, el olvido mismo como distorsión, una inscripción torcida de esos renglones que se imponen (Ge-stell) como mundo de la técnica. Ya Heidegger había señalado que en el Ge-stell se daría el primer centelleo del Er-eignis ${ }^{54}$.

¿En qué consiste entonces la superación (Überwindung) del nihilismo? En la apropiación (Verwindung) de la metafísica. He aquí el extraño pensamiento. A éste procuramos encubrirlo. Nuestra repugnancia sería menor si observásemos cómo este pensamiento implica que la esencia del nihilismo nada tiene de nihilista y cómo también no se despoja a la metafísica de su antigua dignidad por el hecho de que el nihilismo se acoja en el interior de su propia esencia. Desde este punto de vista, por tanto, es preciso reconocer que la superación de la metafísica no consiste en otra cosa que en el desvelamiento de una verdad latente desde el origen. En realidad, la antimetafísica de Heidegger no puede juzgarse desde Nietzsche. Si para Heidegger el pensador de Basilea permanece siendo metafísico, desde el punto de vista de Nietzsche, el metafísico es Heidegger ${ }^{55}$.

En conclusión, cuando Heidegger afirma pensar la verdad de la metafísica no hace otra cosa que asumir explícitamente la misión del metafísico. La confrontación del pensamiento de Heidegger con el de Nietzsche corresponde a uno de los momentos capitales del filosofar heideggeriano donde deja de lado múltiples renglones en los que Nietzsche escapa a su dictamen. La utilización de los fragmentos de una obra incumplida como Der Wille zur Macht es, a todas luces, y en el mejor de los casos, un malentendido. En esta confrontación se pone de relieve los límites del pensamiento del filósofo de la Selva Negra. Esto es innegable.

La filosofía se estremece con Nietzsche. ¿Pero esto ocurre sólo porque sería el último de los filósofos, el último de los metafísicos? (Cada filósofo es siempre el último.) ¿O más bien porque lo llama un lenguaje totalmente otro, la escritura de fractura, cuya vocación sería la de suponer las palabras tachadas, espaciadas, puestas en cruz, dentro del movimiento que las aparta, pero también las retiene, en este apartamiento como lugar de la diferencia, debiendo así confrontar una exigencia de ruptura que lo desvía constantemente de todo lo que

53. Cf. L. Laiseca, El nibilismo europeo, op. cit., pp. 303-304.

54. M. Heidegger, Identität und Differenz, Pfullingen: Neske, 1957, p. 27.

55. Mónica B. Cragnolini escribió que Heidegger dejó de lado «el reconocimiento del carácter producido de las ideas de sujeto y de yo» que es lo que permitiría «la utilización de las mismas como 'errores útiles'. Si consideramos que sólo hay voluntad de poder, fuerzas que se caracterizan en su crecimiento más por la disgregación que por la aglutinación, y admitimos que la voluntad de poder se expresa sobre todo como fuerza interpretativa, toda posibilidad del decir acerca de la misma exigirá el uso de ciertas categorías 'unificantes'. Aquí ‘soñamos' sabiendo lo que hacemos: utilizamos determinados conceptos reconociendo su carácter de error —en tanto estatificación de la fuerza, de lo deviniente, del continuum -, pero también su necesidad. Sólo la necesidad de un mundo formulable, logicizable, comprensible, nos obliga a la categoría de sujeto", como a las categorías de causalidad, racionalidad, orden, progreso, etc. Cf. M. B. Cragnolini, Moradas Nietzscheanas. Del sí mismo, del otro y del «entre», Buenos Aires: La Cebra, 2006, p. 113. 
tiene poder de pensar? ¿Cuál sería entonces esta exigencia si suponemos que nosotros mismos, a quienes detiene, podemos designarla sin interrumpirla, ni ser interrumpidos por ella $^{56}$ ?

Describo lo que viene, lo que no puede venir de otro modo: el surgimiento del nihilismo. Esta historia ya puede contarse desde ahora; porque la necesidad misma está aquí en curso [...] el que aquí toma la palabra, por el contrario, no ha hecho otra cosa que reflexionar [...] como un espíritu profético que mira hacia atrás para contar lo que va a venir; como el primer nihilista consumado de Europa, el cual, sin embargo, ya ha terminado de experimentar el nihilismo en sí mismo — que ya lo tiene detrás de sí, debajo de sí, fuera de sí... ${ }^{57}$.

\section{LA MODERNIDAD Y EL MARTILLO DE NIETZSCHE}

Descreo de la pregunta por la modernidad; pienso que siempre hay una escena que se repite, el sacrificio y el exceso, la ruptura del límite como condición de la subjetividad. La imagen anticipa pero concluye, y otorga la diferencia. Las palabras en la modernidad no funcionan sólo como metáforas sino como articulaciones de la forma, nudos que relacionan los niveles del relato y cumplen en la narración una compleja función constructiva. Así la modernidad, el espacio que habita y que late como esa condición moderna podría haberse resuelto en la Fenomenología del Espíritu, o la Filosofía del dinero, quizá también en un libro tan exquisitamente delicioso como la Crítica de la Razón Pura o un poco más: El Capital. Pero es propio de la razón tener siempre razón. Y aunque hoy sabemos que los saberes y la razón están siempre agujereados, aún seguimos preguntándonos: ¿̇para quién trabaja el saber?

Todas esas obras pudieron siempre parecer libros imaginarios, libros que podrían haber circulado entre la imaginación y lo real, entre el miedo y la locura, porque hay teorías que pueden igualar el delirio; pero no, por lo que se preocuparon esas teorías fue por la formación del sentido, del horizonte, de la continuidad, de la racionalidad, del orden, de la luz; era eso, como si en el fondo de todo se estuviera conjurando lo que sobrevendría: «el martillo de Nietzsche», ese espectro, su retorno que nunca es de la misma manera, porque el regreso del espectro ya ha olvidado su propio vocabulario y por ello mismo nos hace abrir otro espacio del lenguaje.

Era eso: «el martillo de Nietzsche» sólo por lo que de miedo infundía; su sola enunciación ya era como el nombre de un arcano maligno, su sola mención originaba una suerte de doctrina sobre el quebranto de la filosofía misma, de un saber que se desgajaba, goznes que arquitecturaban niveles de maldición, grados de ruptura, de fragmentación, el rompimiento del sentido y del horizonte. Ahí, en esa trama de golpes furiosos, de ese martillar sin espacio y sin sentido, todos podían sentirse llamados y nombrados por él, ahí el sujeto se mostraba como el desecho porque la ciencia es la supresión del sujeto; nada exculpaba a quien fuera

56. En este punto es conveniente remitirse a un espléndido ensayo de Blanchot sobre Nietzsche, cf. M. Blanchot, El diálogo inconcluso, especialmente, «Nietzsche y la escritura fragmentaria», Caracas: Monte Ávila Editores, pp. 252 ss.

57. KSA XIII 189-190, noviembre de 1887 - marzo de 1888, 11[411]. 
mencionado en medio del asombro sarcástico de ese nombre maldito que es el de Friedrich Nietzsche.

Al final de todo estoy persuadido de que al leer, por ejemplo, el Zaratustra, no podemos más que repetir la historia de Don Quijote: realizar en la realidad aquello que se lee. Leemos la repetición, lo que vuelve, el retorno de lo reprimido, el dolor acallado, la muerte blanca, quizá, como dice Piglia: «Habría que hacer una historia de la lectura como venganza». Por ello no creo que podamos preguntarnos si nuestro mundo es todavía «moderno». Aquí sólo he querido dilucidar qué y cómo y por qué en nuestro rostro se ha escrito esa geografía que inaugura y da sentido a nuestro destino y que lleva el nombre de modernidad o como dice Heidegger: metafísica.

Modernidad y metafísica, nombres que, acaso, se tejieron en ese viejo lógos, la «reunión» griega, como nos enseñó Heidegger ${ }^{58}$, de ser y hombre, de cosas y ocasos del decir. Quizá tenía razón Weber al señalar que la modernidad era el tiempo del desencantamiento del mundo acaso porque ella significó el desgarramiento de la organización del tiempo y la ruptura con la tradición, con lo que se organizaba nuestro tiempo y nuestro espacio de otra manera. Hoy, creemos que estamos en el dintel de su agonía. Porque équé ha sido de eso que hoy llamamos «el proyecto de la modernidad»?

Esta es una pregunta de índole mayor. No sólo es difícil definir lo que significa, sino también datar sus orígenes. Pensemos sólo que dentro de un contexto la modernidad es una forma de concebir el mundo, de establecer estrategias de posicionamiento, de comprensión y de transformación en cada época. En este caso particular, la modernidad a la que nos referimos es, más que nada, la expresión de una manera específica de ver y comprender los hechos en el tiempo como continuidad y también como ruptura.

La modernidad parece romper con el pasado y con aquello que la define, incluida la llamada tradición. Pero cesto es así? Baste con recordar las palabras de aquel artículo de Heidegger para hacer un alto sobre el espacio en el que nos debatimos:

En la metafísica se lleva a cabo la meditación sobre la esencia de lo ente así como una decisión sobre la esencia de la verdad. La metafísica fundamenta una era, desde el momento en que, por medio de una determinada interpretación de lo ente y una determinada concepción de la verdad, le procura a ésta el fundamento de la forma de su esencia. Este fundamento domina por completo todos los fenómenos que caracterizan a dicha era y viceversa, quien sepa meditar puede reconocer en estos fenómenos el fundamento metafísico. La meditación consiste en el valor de convertir la verdad de nuestros propios principios y el espacio de nuestras propias metas en aquello que más precisa ser cuestionado ${ }^{59}$.

Es cierto que hoy estamos frente al desencanto de ese proyecto, de sus promesas y de sus sueños pero quizá esto no sea más que la decepción de algo mayor, de eso que para Heidegger constituyó «la consumación de la metafísica», el destino de Occidente. Porque estamos ante la crisis de la metafísica, de su acabamiento, de su fin.

58. M. Heidegger, Vorträge und Aufsätze, 3 vols., Pfüllingen: Neske, 1967 (Conferencias y artículos, ed. de E. Barjau, Barcelona: Serbal). Cf. vol. III, pp. 8, 9 y 11 s.

59. M. Heidegger, «La época de la imagen del mundo», en Caminos de bosque, op. cit. 